Inga Staal Jenset

Universitetet i Oslo

Marte Blikstad-Balas

Universitetet i Oslo

DOI: https://doi.org/10.5617/adno.8153

\title{
Ny praksisform i lærerutdanningen: Analysepraksis for forsknings- og profesjonsforberedelse
}

\begin{abstract}
Sammendrag
Det er et tilbakevendende tema at lærerutdanningen må være forankret i praksis i større grad, og at lærerstudenter fremhever nettopp praksiserfaringene som det mest verdifulle i studiene. I tråd med internasjonal forskning på alternative måter å gjennomføre praksis på, har lektorprogrammet ved Universitetet i Oslo utviklet fem dager med såkalt analysepraksis - en praksisform der studentene er på campus og der all undervisning tar utgangspunkt i en konkret case med videoer av undervisning, intervjuer med elever og lærer, dokumenter fra timer og spørreskjemaer elevene har besvart, alt fra fire skoletimer i samme klasse. I artikkelen undersøker vi, ved hjelp av både spørreskjema og fokusgrupper, i hvilken grad lektorstudentene oppfatter at en slik praksisorganisering har bidratt til deres forsknings- og profesjonsforberedelser. Funnene viser at studentene er positive til alternative praksisformer, at de opplever analysepraksis som relevant for egen masteroppgave, og at det å analysere artefakter fra praksis er en progresjon fra tidligere praksisperioder. I diskusjonen tar vi opp hvordan studentene kan utfordres på at det å kjenne til ulike forskningsmetoder og analytiske innganger ikke bare er noe som angår forskere og masterstudenter - men alle profesjonelle lærere som skal forholde seg til forskning gjennom hele yrkeslivet.
\end{abstract}

Nøkkelord: lærerutdanning, praksis, videodata, «learning to notice»

\section{Innovative design of fieldwork in teacher education: Using artefacts of practice to prepare for teaching and research in the profession}

\begin{abstract}
There is consensus that teacher education has to be grounded in practice to a larger extent, and teacher students often mention their fieldwork or practice period as the most valuable part of their teacher training. Following international resesarch on alternative ways to implement practice in teacher education, the teacher education programme at the University of Oslo has developed a five day intensive "analytical practice" course a campus-based form of practice where all teaching activities are grounded in an empirical classroom case where one class is followed over four consecutive lessons. The case includes videos of the lessons, interviews with the teacher and some students,
\end{abstract}


documents from the lessons and a survey with students in the class. In the present study we draw on survey data and focus group interviews to investigate the degree to which “analytical practice” has contributed to teacher students' professional understanding both of teaching and of educational research that can inform teacher practices. Findings show that the students are positive towards alternative practice forms like "analytical practice", they experience it as relevant for their own research in their master thesis, and they express that this form of practice is a progression from earlier practicum periods. In the discussion we address how students can be challenged on the issue of relevance - and on why research methods and analytical approaches are not something that only concern researchers and master students, but all professional teachers who actively engage in research throughout their careers.

Keywords: teacher education, practice, video data, learning to notice

\section{Bakgrunn og formål}

Det er et stadig tilbakevendende tema at lærerutdanningen må være forankret i praksis i større grad, både internasjonalt (Darling-Hammond et al., 2017; Hammerness et al., 2020; Jenset et al., 2018) og i Norge (Finne et al., 2014; NOKUT, 2006). Lærerstudenter fremhever ofte praksiserfaringene som det mest verdifulle i studiene (Ulvik et al., 2018), og på bakgrunn av dette er omfanget av praksis i norsk lærerutdanning økt (Kunnskapsdepartementet, 2014). Samtidig som studentene fremhever betydningen av praksis, vet vi at det ofte er en rekke utfordringer forbundet med å sikre god nok kvalitet i praksisopplæringen (Darling-Hammond et al., 2005; Grossman et al., 2008), og at en økning i antall praksisdager derfor i seg selv ikke kan antas å øke lærerutdanningens relevans eller kvalitet. Økt omfang av praksis stiller også større krav til praksisveilederne i skolen, noe som kan være en kapasitetsmessig utfordring (NOKUT, 2019). I Norge har det de siste årene vært stort fokus på kvalitetssikringen av praksisopplæringen i lærerutdanningene (Lejonberg, 2018). Etableringen av universitetseller lærerutdanningsskoler er ett ledd i denne kvalitetssikringen (Lund \& Eriksen, 2016; Kunnskapsdepartementet, 2017). Også veilederkompetanse, og heving av denne, er på dagsorden (Kunnskapsdepartementet, 2018; Lejonberg, 2018; Rambøll, 2021).

Forskere har gjentatte ganger argumentert for at lærerstudenter trenger mye støtte og veiledning for å ha utbytte av praksisopplæringen (Darling-Hammond et al., 2005; Jenset et al., 2019; Fosse, 2011; Lejonberg \& Tiplic, 2016). Men hva skal regnes som praksis? Selv om mange trolig forbinder praksis med det Ball og Cohen (1999, s. 14) omtaler som «situations in school classrooms in real time», argumenterer forskere i økende grad for at en praksisbasert lærerutdanning ikke nødvendigvis trenger å bety at studentene tilbringer mer tid i skolene, men at man kan bringe ulike artefakter fra praksis inn i undervisningen på campus (Ball \& Cohen, 1999; Grossman, Hammerness et al., 2009; Jenset et al., 2018). Forskerne tar til orde for at slik bruk av datamateriale fra skolen, som video fra klasserom 
og andre artefakter fra praksis, kan være et godt alternativ til praksis i skoler. Gjennom systematisk tilnærming til artefaktene kan studentene få øvelse i å legge merke til og reflektere rundt vesentlige hendelser i klasseromsundervisningen, noe som fremstilles som en avgjørende ferdighet for kommende lærere (Blömeke et al., 2015; Seidel \& Stürmer, 2014; Sun \& van Es, 2015). I denne artikkelen legger vi til grunn et slikt bredt praksisbegrep, som går ut over det å være til stede i et klasserom «der og da». I tråd med Ball og Cohen (1999, s. 14), inkluderer vi såkalt «strategisk dokumentasjon av praksis» i praksisbegrepet til grunn for lærerutdanningen; det vil si at det å tilnærme seg artefakter som elevarbeider, video og lydopptak, undervisningsmateriell og læreres notater til timen og granske dette ut over det som er mulig i en reell klasseromssituasjon, vil kunne utgjøre et viktig bidrag til lærerstudentenes praksis.

Mot dette bakteppet ble innføringen av 100 dager praksis for de integrerte lektorutdanningene (Kunnskapsdepartementet, 2013) et godt utgangspunkt for å tenke nytt rundt organiseringen av praksis ved lektorprogrammet ved Universitetet i Oslo (UiO). Fra 2018 har alle lektorstudenter ved UiO fått 15 dager praksis knyttet til masterspesialiseringen i sitt 9. semester, fordelt mellom fem dager analysepraksis og ti dager forskningspraksis. I denne artikkelen vil vi fokusere på analysepraksis, som er en ny obligatorisk praksisform for studentene som er lagt til campus. I denne artikkelen undersøker vi i hvilken grad og hvordan lektorstudentene oppfatter at en slik praksisorganisering har bidratt til deres forsknings- og profesjonsforberedelser.

\section{Utfordringer knyttet til kvalitetssikring av praksis}

Praksisopplæringen i norsk lærerutdanning har hatt store utfordringer over tid (NOKUT, 2019). Praksisen oppleves ikke som helhetlig, og heller ikke som integrert i det overordnede studiedesignet. Evalueringene finner også at lærerutdanningsinstitusjonene og praksisfeltet har noe ulike oppfatninger om hva som kjennetegner en god lærerutdanning (Finne et al., 2011; Finne et al., 2014; Finne et al., 2017). Studentene kan dermed oppleve at det er motsetninger mellom det de erfarer og lærer på campus og det de erfarer og lærer i praksisperiodene. På samme måte viser evalueringer av nyutdannede at det kan være tilfeldig om de får veiledning, på hvilken måte den eventuelt gjennomføres, og hvilken kompetanse veilederne har (Rambøll, 2016, 2021). Nasjonale retningslinjer setter krav til omfang av praksis i lærerutdanningene, men det er ingen krav til innhold og veiledning (Kunnskapsdepartementet, 2013). Selv om mange kanskje hadde håpet på nasjonale krav om veilederutdanning for veiledere i lærerutdanningen og mentorer for nyutdannede i skolen, er det foreløpig kun vedtatt prinsipper og forpliktelser for veiledning av nyutdannede nytilsatte lærere i barnehage og skole, samt en skriftlig faglig veileder om hvordan gode veiledningsordninger kan utformes og gjennomføres lokalt (Kunnskapsdepartementet, 2018). 
Sammen med etableringen av utdanningstilbud for veiledere utgjør disse elementene de nasjonale rammene for veiledning, som er ett av tiltakene i strategien Lærerutdanning 2025 (Kunnskapsdepartementet, 2017). Forskningen levner liten tvil om at god veiledning er viktig for lærerstudentenes utbytte av praksisopplæringen: God veiledning bidrar til at lærere blir værende i jobben (Ingersoll \& Strong, 2011), at de har tro på egen evne til å mestre arbeidsoppgavene (Lejonberg \& Tiplic, 2016; LoCasale-Crouch et al., 2012), og veiledning letter overgangen til yrkeslivet (Rambøll, 2016). En studie på lærerstudenters praksiserfaringer i norsk kontekst viser at veilederne spiller en avgjørende rolle for studentenes læringsutbytte, men at veiledning stort sett er et privat anliggende, og at større grad av samarbeid veiledere imellom kunne sikret en mer koordinert praksisopplevelse for studentene (Ulvik et al., 2018). Det er derfor gledelig at en evaluering av veiledningsordningene viser at selv om tilbudene varierer mye, så er veilederne fornøyde med tilbudet, og ordningen blir ansett som viktig for kompetanseutvikling i den enkelte institusjon og profesjonen generelt (Rambøll, 2016). Rapporten konkluderer med at evalueringen indikerer «at veilederutdanningen har betydning for kvaliteten på veiledningen» (s. 80).

Styrking av partnerskapene mellom skolene og lærerutdanningsinstitusjonene er også avgjørende for å gjøre lærerutdanningen mer praksisrelevant, og å kvalitetssikre praksisopplæringen. Etablering av slike partnerskap er ikke nytt, men har pågått i alle fall siden 1980-tallet, med erfaringer fra England, USA, Nederland og Finland (Lillejord \& Børte, 2014). I norsk sammenheng er lærerutdanningsskoler nå lansert som en nasjonal strategi (Kunnskapsdepartementet, 2017), basert på erfaringer med universitetsskoler ved universitetene i Oslo (Lund \& Eriksen, 2016) og Tromsø (Rørnes, 2015). En forskningsoppsummering av partnerskap i lærerutdanningen (Lillejord \& Børte, 2014) peker på at det også er utfordringer med slike partnerskapsmodeller, da det er utfordrende å etablere symmetriske og jevnbyrdige relasjoner mellom opplæring på campus og i praksis. Heri inngår utfordringen med å etablere jevnbyrdige partnerskap, eller det man ofte definerer som «tredje rom». Foreløpig bidrar forskningen i større grad med å peke på utfordringer enn løsninger på dette feltet (Lillejord \& Børte, 2014).

Også andre satsinger bidrar til å kvalitetssikre praksisopplæringen i lærerutdanningen. I Norge har for eksempel fokuset på en forskningsbasert lærerutdanning blitt en måte å støtte lærerstudentene i deres læring underveis i praksis (Kunnskapsdepartementet, 2009; Munthe \& Rogne, 2015), og dette skjer også i stor grad som samarbeid mellom lærerutdanningsinstitusjonene og skolene. Conway og Munthe (2015) kaller dette en «research-informed clinical practice turn» (s. 148), og fremhever viktigheten av at det forskningsbaserte inkluderer lærerstudentenes egen kritiske undersøkelse av praksis. Dette fokuset finner vi også i internasjonal forskning, der det argumenteres for at integrering av lærerstudenters eget forsknings- og utviklingsarbeid kan hjelpe lærerstudenter til å kritisk evaluere og undersøke sin egen praksis på en systematisk måte (Cochran- 
Smith \& Lytle, 2009; Jyrhämä et al., 2008; Krokfors et al., 2011; Ulvik \& Riese, 2016). For eksempel snakker Cochran-Smith \& Lytle (2009) om «inquiry as stance», (s. viii) som en måte å tilnærme seg praksis undersøkende og kritisk på.

I den finske konteksten er fokuset på en forskningsbasert lærerutdanning stort, og Krokfors et al. (2011) finner at en slik tilnærming må skje i nær sammenheng med praksis og skolens hverdagsliv for at lærerstudentene skal kunne utvikle en kritisk og undersøkende tilnærming til egen praksis. På samme måte argumenterer Ulvik og kollegaer i norsk kontekst for bruken av aksjonsforskning i lærerutdanningen, men advarer om at dette er utfordrende og tidkrevende, og forutsetter støttestrukturer og relevante ressurser (Ulvik, 2014; Ulvik \& Riese, 2016). Også Lesson Study fremheves som en tilnærming til praksisopplæringen som gir lærerstudenter større grad av støtte i sin læringsprosess. Lesson Study er en opprinnelig japansk systematisk tilnærming til undervisning, der lærere sammen planlegger, gjennomfører og reflekterer over en undervisningssekvens (Lewis \& Tsuchida, 1997; Parks, 2008; Stigler \& Hiebert, 1999). I norsk kontekst har bruk av Lesson Study som metode for eksempel vist at dette kan hjelpe lærerstudenter til i større grad å fokusere på elevenes læring, heller enn sin egen opptreden som lærere mens de er i praksis (Helgevold et al., 2015). Andre funn indikerer at denne metoden kan bidra til at lærerstudentene i større grad involveres i genuin forskningsorientert samarbeidslæring der de genererer forskningsspørsmål og gjør kritiske undersøkelser av egen praksis (Munthe et al., 2016).

Oppsummert har det de siste årene vært et stort fokus på å kvalitetssikre lærerstudenters praksiserfaringer, og det er mange og ulike tilnærminger til dette. Men det er ikke bare praksisopplæringen ved lærerutdanningen som har utfordringer. Lærerutdanningen har også vært sterkt kritisert for manglende samsvar mellom teoriopplæringen og praksisopplæringen - både internasjonalt (DarlingHammond et al., 2017; OECD, 2005), og i Norge (Finne et al., 2014; NOKUT, 2006). Vi vender oss derfor nå til forskning på praksisbaserte undervisningspraksiser i lærerutdanningen, som er fokus for denne artikkelen.

\section{Praksisbasert undervisning i lærerutdanningen}

Forskning viser at nyutdannede lærere ofte ikke er godt nok forberedt for det praktiske arbeidet som lærere (Kennedy, 1999; Rambøll, 2016), og begreper som "praksissjokk» er ofte brukt for å beskrive overgangen fra utdanning til profesjon (Caspersen \& Raaen, 2014; Meijer et al., 2011; Smith et al., 2013). Videre har det vært uttrykt bekymring over at lærings- og undervisningsformene i utdanningene er for tradisjonelle, med fokus på lærerstyrt formidling og forelesninger (Kunnskapsdepartementet, 2017). Over hele verden argumenterer derfor forskere, politikere og lærerutdannere for behovet for å utvikle og benytte mer relevante lærings- og undervisningsformer i lærerutdanningen, relatert til læreres praktiske 
arbeid (se for eksempel Ball \& Cohen, 1999; Hammerness et al., 2005; NOKUT 2006).

Som allerede nevnt, argumenterer ikke forskerne nødvendigvis for økt omfang av tradisjonell praksis i skolene, men fremhever campus som en viktig setting for å sentrere lærerutdanningen mer rundt praksis. For eksempel argumenterte Ball og Cohen (1999) for en grunnleggende nytenkning rundt design av lærerutdanningsprogram. De så for seg at lærerutdanningen kunne bli mer praksisbasert ved at artefakter fra praksis kunne katalogiseres og gjøres tilgjengelige for lærerutdannere, og inngå i lærerutdanningens pensum. De presiserte at dette ville være en stor omveltning for lærerutdanningene, som ville kreve stor grad av profesjonell utvikling for lærerutdannere (Ball \& Cohen, 1999). Grossman, Hammerness et al. (2009) argumenterer langs samme linje når de tar til orde for å gjenskape lærerutdanningen organisert rundt spesifikke kjernepraksiser som er frekvente og relevante i lærerprofesjonen (Ball \& Forzani, 2009; Forzani, 2014; Lampert et al., 2013). Grossman, Hammerness et al. (2009) presiserer at en slik organisering av lærerutdanningen krever en total nytenkning av hvordan man forstår utdanningen og sammenhengen mellom teori og praksis og mellom campus og skoler - men argumenterer for at en slik endring er avgjørende for å imøtekomme den gjentagende kritikken av lærerutdanningen. En slik tilnærming til lærerutdanning er lite etablert i norsk kontekst (Jenset, 2020), selv om det finnes unntak den siste tiden (Mosvold et al., 2018; Wæge \& Fauskanger, 2020).

Innenfor forskning på lærerutdanning fremheves bestemte praksisbaserte undervisningspraksiser som spesielt viktige. Grossman, Compton et al. (2009) foreslo for eksempel et rammeverk for slike undervisningspraksiser gjennom «representations», «decompositions» og «approximations» av praksis. Komplekse praksiser lærere benytter burde ifølge Grossman, Compton et al. (2009) illustreres for lærerstudentene, for eksempel gjennom video eller modellering, og brytes ned i mindre deler ved å sette begreper på det man ser. Lærerstudentene burde så få muligheter til å delta i aktiviteter som tilnærmer seg disse praksisene, ved at de får øve på dem på campus, for eksempel før de skal brukes med elever i skolen (Grossman, Compton et al., 2009). I forlengelsen av denne forskningen har andre forskere foreslått lignende pedagogiske rammeverk i form av en læringssyklus i fire faser bestående av en introduksjon til en kompleks praksis; øvelse på praksisen; gjennomføring av praksisen med elever; og analyse av og refleksjon over egen praksis (McDonald et al., 2013). Andre, lignende pedagogiske rammeverk er beskrevet av Lampert et al. (2013) og Hiebert et al. (2007).

\section{«Learning to Notice»}

I forlengelsen av forskningen på praksisbaserte undervisningspraksiser i lærerutdanningen viser flere studier at bruk av videoer har et stort potensial (Brophy, 2004; Gaudin \& Chaliès, 2015; Sun \& van Es, 2015). Bruk av video i profesjonsopplæringen har flere fordeler i denne sammenheng: Det gir direkte tilgang til profesjonsutøvelsen (for eksempel opptak av undervisnings- og lærings- 
situasjoner fra klasserommet), det beholder autentisiteten i situasjonen, og det muliggjør en bedre sammenheng mellom teoretisk kunnskap i kursene i lærerutdanningen og den praktiske erfaringen studentene får fra praksisskolene (Gaudin \& Chaliès, 2015).

I en stor forskningsgjennomgang om bruken av video i lærerutdanningen viser Gaudin og Chaliès (2015) til to sentrale prosesser studentene må delta aktivt i når videoer brukes i en undervisningsaktivitet. Selektiv oppmerksomhet fremheves som den primære prosessen, altså det å lære å legge merke til relevante hendelser i videoene. Mange studier konseptualiserer denne prosessen som «learning to notice» (Barnhart \& van Es, 2015; Seidel \& Stürmer, 2014; Sherin et al., 2010) eller «perception» (Blömeke et al., 2015). Videre identifiserer Gaudin og Chaliès (2015) refleksjon som en annen prosess når studentene ser på video. Dette innebærer tolkningen eller analysen av utvalgte hendelser i klasseromsvideoene, og lærerstudentenes evne til å reflektere rundt disse hendelsene basert på sin kunnskap om undervisning og læring (Seidel \& Stürmer, 2014).

Studier viser at lærerstudenters evne til å legge merke til og analysere relevante undervisningshendelser kan forbedres ved bruk av video («learning to notice», se for eksempel Barnhart \& van Es, 2015; Seidel \& Stürmer, 2014; Sun \& van Es, 2015). Noen av disse studiene har systematisk etterfulgt sammenhengen mellom evnen til å analysere eller diagnostisere situasjoner med utgangspunkt i videoer og kvalitetene ved studentenes undervisningspraksis (Barnhart \& van Es, 2015; Sun \& van Es, 2015). Selv om praksis oppleves som autentisk når man er tilstede $i$ et klasserom og situasjonen utspiller seg, er undervisning en så kompleks og umiddelbar aktivitet (Forzani, 2014) at de færreste undervisningssituasjoner muliggjør at en kan fordype seg i lærerstudentens handlinger og reflektere systematisk over disse der og da. Flere studier viser at bruken av praksisrelaterte læringsaktiviteter slik som for eksempel simuleringer, video case og lignende, faktisk kan ha større effekt på lærerstudentenes profesjonstilegnelse enn å øke omfanget av praksis i skoler (Metcalf et al., 1996).

Erfaring med bruk av video kan også være relevant for lærerstudentene fordi det å diskutere autentiske filmklipp kan inngå i læreres utvikling av egen praksis innenfor rammene av et profesjonsfellesskap (Aranda et al., 2019). For at slike diskusjoner skal være fruktbare, er det som tidligere nevnt viktig at de er fokuserte nok og at deltagerne er enige om observasjonsfokus og hva de skal reflektere over. At lærerstudentene har erfaring med denne type fokusert samtale fra utdanningen, vil dermed være en fordel.

\section{Metode}

\section{Studiens kontekst: En uke analysepraksis}

Analysepraksis er en ny praksisorganisering utviklet ved Institutt for lærerutdanning og skoleforskning ved Universitetet i Oslo, i samarbeid med det nordiske 
senteret for fremragende forskning QUINT - Quality in Nordic Teaching - der et av fire hovedområder nettopp er bruk av videodata i lærerutdanningen. Konseptet i analysepraksis er at studentene over en uke på campus arbeider i grupper med en praksiscase. Praksiscasen er tatt fra en klasse i norsk på sitt andre år i videregående skole med 21 elever, og følger klassen i en fire-timers undervisningsøkt om litteratur og språk på 1800-tallet. Temaet i undervisningen som filmes er «Forestillingen om det norske», og økta inneholder både lærermonolog, gruppearbeid, elevfremføringer og diskusjoner i helklasse. Læreren i casen er en erfaren lærer som var villig til å bidra til filmer hun visste skulle analyseres og diskuteres grundig over flere dager. Elevene som ble filmet ble også informert grundig i forkant og fikk stille spørsmål om hva deltagelse innebar. Det ble innhentet skriftlig og informert samtykke fra både lærer og elever i klassen, i tråd med god forskningsetikk.

En sentral ambisjon med analysepraksis er at studentene gjennom ulike datakilder hentet fra denne casen vil få økende grad av innblikk i undervisningen. Tabell 1 viser oversikt over de ulike datakildene studentene får innblikk i:

Tabell 1. Datakilder studentene møter i analysepraksis

\begin{tabular}{|l|l|}
\hline Datakilde & Hva kan disse dataene gi innsyn i? \\
\hline $\begin{array}{l}\text { Dokumentdata } \\
\text { Lærerens undervisningsplan for timen; } \\
\text { lærerens PowerPoint; } \\
\text { hand-outs (tekster og oppgaveark) }\end{array}$ & $\begin{array}{l}\text { Kan gi innsyn i planlagt undervisning og innblikk i } \\
\text { hva slags ambisjoner læreren har for den aktuelle } \\
\text { øta }\end{array}$ \\
\hline $\begin{array}{l}\text { Videodata } \\
\begin{array}{l}\text { Fire timer undervisning, filmet med flere } \\
\text { kameraer simultant for å fange opp både } \\
\text { helklasse og grupper }\end{array}\end{array}$ & $\begin{array}{l}\text { Kan gi innsyn i hvordan undervisningens ulike } \\
\text { sekvenser gjennomføres av læreren og elevene, og } \\
\text { hva elevene gjør i ulike grupper }\end{array}$ \\
\hline $\begin{array}{l}\text { Intervju med lærer } \\
\text { Lydopptak og transkripsjon av intervju med } \\
\text { lærer om hvordan hun pleier å jobbe, samt } \\
\text { konkrete spørsmål om økta som er filmet }\end{array}$ & $\begin{array}{l}\text { Kan gi innsyn i lærerens refleksjoner over egen } \\
\text { praksis }\end{array}$ \\
\hline $\begin{array}{l}\text { Videointervju med elever (N=4) om } \\
\text { hvordan de opplever timene med den } \\
\text { aktuelle læreren }\end{array}$ & $\begin{array}{l}\text { Kan gi innsyn i hvordan disse fire elevene opplever } \\
\text { læreren og undervisningen }\end{array}$ \\
\hline $\begin{array}{l}\text { Surveydata hvor elevene vurderer } \\
\text { undervisningen (N=21) }\end{array}$ & $\begin{array}{l}\text { Kan gi innsyn i hvordan elevene samlet vurderer } \\
\text { lærerens undervisning ut ifra en rekke parametere, } \\
\text { samt i hvor stor grad elevene er samstemte i sine } \\
\text { vurderinger }\end{array}$ \\
\hline
\end{tabular}

Uka med analysepraksis er intensiv, og organiseres som forelesninger og seminarer hver dag mandag-onsdag 10-16 der studentene får innføring i de ulike datakildene, før de selv skal arbeide systematisk med disse gruppevis i seminar. I tråd med «learning to notice»-tankegangen er det et viktig prinsipp at studentene får konkrete forhold i undervisningen de skal følge ekstra godt med på, snarere enn å komme med generelle betraktninger. Det forventes at studentene skal kunne begrunne utsagn om lærerens praksis med konkrete eksempler. Det er også lagt opp til at studentene skal få erfaring med en rekke ulike måter å systematisere eller kode - observasjonene sine på. For eksempel får de i oppgave å transkribere 
og kode induktivt et videoklipp i det første seminaret, mens de i senere seminarer skal utvikle et enkelt kodeskjema og bruke dette og andre forskningsbaserte og teoridrevne observasjonsmanualer til å kode ulike datakilder deduktivt. Slik får studentene øvelse i bruk av ulike typer analysemetoder og -instrumenter for å legge merke til ulike sider ved undervisningscasen. De får også praktisk erfaring med utfordringer knyttet til inter-rater reliabilitet og datatriangulering, for å nevne noe.

Onsdag ettermiddag får studentene, i grupper på 3 eller 4, utdelt hvert sitt «ukesoppdrag» med gitte problemstillinger knyttet til undervisningscasen, som de skal besvare med bruk av ulike (gitte) datakilder og ulike analytiske tilnærminger. Resultatene av ukesoppdragene presenteres på et avsluttende forskningssymposium på fredagen der studentene deltar med enten foredrag (key notes) eller poster til et postertorg. Forskningssymposiet er åpent for publikum.

Figur 1 oppsummerer hovedtrekkene i uka:

Figur 1. Oppsummering av datakilder og arbeidsmetoder benyttet i analysepraksis. Både i seminarer, i forelesninger og i gruppearbeidene blir det arbeidet med ulike former for analyse (induktiv, deduktiv, abduktiv) samt ulike metodetrianguleringer.

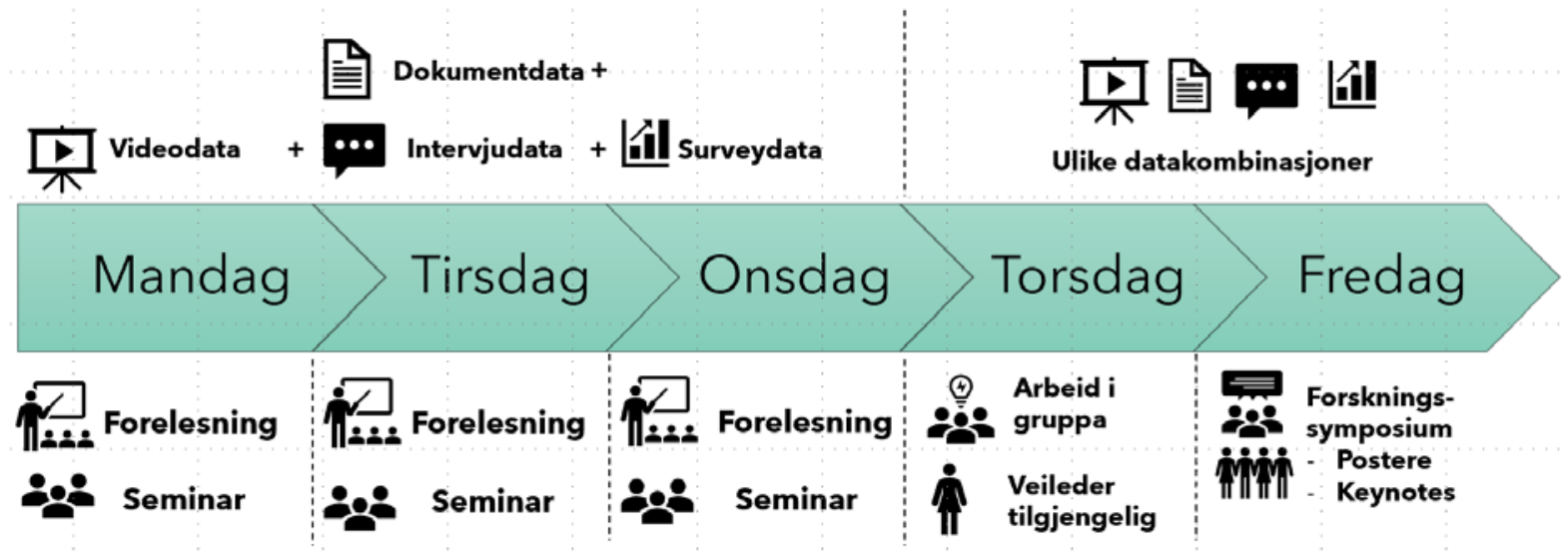

\section{Deltagere, datakilder og analyse}

Denne studien rapporterer fra gjennomføringen av analysepraksis ved UiO høsten 2019 med 75 lektorstudenter i 9. semester. Dette var andre gang analysepraksis ble gjennomført. Studien har data i form av studentenes $(\mathrm{N}=37)$ tilbakemeldinger på et spørreskjema med en kombinasjon av åpne og lukkede spørsmål, og «stimulated recall»-intervju ( $\mathrm{N}=4)$. Spørreskjemaet var en frivillig evaluering i nettskjema to uker etter gjennomføring av analysepraksisuka. Svarprosenten var $49 \%$, noe som er en relativt god svarprosent på digitale spørreskjema av denne typen (Sauermann \& Roach, 2013). I skjemaet kunne studentene velge om dataene kunne brukes i forskning eller ikke, og samtlige studenter takket ja til at svarene deres kunne brukes i anonymisert form i analysene vi rapporterer her. Basert på funnene i spørreundersøkelsen rekrutterte vi fire studenter som til sammen ga god spredning i overordnet «fornøydhet» med uka, til to semistrukturerte parintervju der fokus var på læringsutbytte av uka relatert til forsknings- og profesjonsforberedelser. Parintervju ble valgt som intervjuform i håp om at studentene ville 
kommentere på hverandres ytringer, og slik generere mer informasjon enn om de hadde blitt intervjuet individuelt (jf. Kvale \& Brinkmann, 2009). Intervjuene var såkalte «stimulated recall» (Calderhead, 1981; Lyle, 2003), hvor artefakter fra analysepraksisuka ble brukt for å bidra til varierte, men spesifikke, refleksjoner knyttet til erfaringer fra uka. Intervjueren fokuserte hovedsakelig på de spesifikke oppgavene studentene arbeidet med i seminarene, samt ukesoppdragene og opplevelsen av uka som helhet. Intervjuene ble tatt opp på bånd og er transkribert.

Spørreskjema og intervju er kodet tematisk med fokus på studentenes erfaringer med uka, relatert til deres forsknings- og profesjonsforberedelse. Vi etablerte koder i tråd med tradisjonell innholdsanalyse (Hsieh \& Shannon, 2005; Fauskanger \& Mosvold, 2014). I utgangspunktet så vi etter koder relatert til «praksis» eller «profesjon», og også «master-», «metode» og lignende, men vi var dessuten åpne for at andre koder ville oppstå etter gjentagende ytringer fra respondentene. Studentene i intervjuene er gitt pseudonymer.

\section{Resultater og diskusjon}

\section{Analysepraksis er «annerledes praksis»: et skarpere blikk?}

Et helt vesentlig spørsmål for oss har vært om studentene opplever analysepraksis som praksis - og om de opplever at de har blitt bedre til å reflektere systematisk over egen og andres undervisning. Overordnet melder de fleste studentene at analysepraksis har vært annerledes enn de andre praksisperiodene de har hatt tidligere i profesjonsutdanningen, og mange av studentene peker på at denne praksisperioden har vært en overgang til «et tydeligere forskningsblikk enn annen praksis», som kan tolkes som at denne praksistilnærmingen har vært en mer systematisk måte å lære seg å legge merke til praksis på. Når studentene ble spurt om i hvilken grad analysepraksis har økt deres kompetanse i å legge merke til og reflektere rundt vesentlige aspekter ved egen og andres undervisningspraksis, svarer nesten alle at det har gjort det i noen grad (se tabell 2).

Tabell 2. Fordeling av svar på spørsmålet: I hvilken grad har analysepraksis økt din kompetanse i å legge merke til og reflektere rundt vesentlige aspekter ved egen og andres undervisningspraksis?

\begin{tabular}{|l|c|}
\hline \multicolumn{1}{|c|}{ Svar } & Antall \\
\hline I svært stor grad & 7 \\
\hline I stor grad & 14 \\
\hline Middels & 14 \\
\hline I mindre grad & 2 \\
\hline I liten grad & 0 \\
\hline
\end{tabular}

21 studenter melder at de mener at analysepraksis har økt deres kompetanse i å legge merke til og reflektere rundt vesentlige aspekter ved egen og andres undervisningspraksis i stor eller svært stor grad, mens 14 svarer middels. Kun to studenter svarer i mindre grad. 
Studentene utdyper dette i de åpne spørsmålene med uttalelser som at de gjennom analysepraksisen ble «mer trent i strukturert observasjon enn jeg har gjort tidligere», og at denne praksisen hadde «mer fokus på analyse og ikke bare observasjon. Sette ting i sammenheng, se mønstre». Dette er vesentlige aspekter ved et «learning to notice»-rammeverk, som fremhever slike egenskaper som avgjørende for at lærere skal være i stand til å ta informerte avgjørelser og legge til rette for videre undervisning (Gaudin \& Chaliès, 2015).

Basert på studentenes utsagn kan det virke som at analysepraksis har oppfylt den funksjonen den skulle ha i å trene studentene i å «legge merke til og reflektere rundt vesentlige aspekter ved undervisningspraksis», i tråd med forskningen gjengitt over. Det er åpenbart at studentene opplever analysepraksis som noe annet enn de praksisperiodene de har hatt tidligere i profesjonsstudiet, og de peker spesifikt på at de har tilegnet seg en kompetanse som de «ikke har vært introdusert til under tidligere praksisperioder». Dette kan tyde på at en praksisperiode basert på et rammeverk som «learning to notice» kan representere en progresjon i studentenes praksis, akkurat slik nasjonale retningslinjer legger opp til (Kunnskapsdepartementet, 2013).

Det er et viktig funn at flere av studentene opplever at et fokus på å analysere praksis har manglet i profesjonsstudiet frem til nå, og en kommentar til det synes nødvendig. For det er selvsagt ikke slik at studentene ikke har «analysert praksis» tidligere i studiet. Lærerutdanningsprogrammet disse studentene følger har fokus både i forelesninger, på seminarer og i pensumlitteraturen på at ulike forskningsmetoder kan brukes både i forskning og som verktøy i læreres kontinuerlige profesjonsutvikling. Men det kan virke som at når det tidligere i studiet har blitt vektlagt å observere praksis i form av å skille mellom beskrivelser og analyse, viktigheten av å ha et observasjonsfokus, det å være bevisst på feilkilder og bruk av observasjonsinstrument etc., så har ikke studentene nødvendigvis opplevd dette som en forskningstilnærming til praksis, eller erfart at det handler om å tolke og analysere praksis. Det kunne vært interessant å undersøke dette nærmere, altså hva som skal til før studentene opplever at for eksempel samtaler om konkrete praksisaspekter eller artefakter innebærer «analyse av praksis».

Som vi viste til i forskningsgjennomgangen, er det store utfordringer med kvalitetssikring av lærerstudenters praksis, og mye vil avhenge av faktorer på hver enkelt skole som det er vanskelig for lærerutdanningen å forutsi eller følge opp. Lærerutdanningsinstitusjonene kan i mye større grad ha innsyn i og kvalitetssikre analysepraksis organisert på campus, og de kan detaljplanlegge hvilke konkrete erfaringer de ønsker at studentene skal ha med seg etter endt praksisuke. Dette påpeker også en student som skriver i spørreskjemaet: «Jeg tror praksiserfaringene (vanligvis) er forskjellige fra student til student - denne uka fikk alle mer eller mindre de samme erfaringene. Det var motiverende fordi da vet jeg at jeg lærer nettopp det ILS vil at jeg skal lære.»

I intervjuene tar vi opp det helt konkrete spørsmålet om hvorvidt denne uka med arbeid på campus «egentlig er praksis». Studentene uttrykker her et tydelig 
skille mellom «å lære mer om analyse» og «praksis». Nina forteller at flere medstudenter har diskutert denne problemstillingen:

Nina: Det var vel mye diskusjoner etter at vi hadde hatt analysepraksis om altså hvordan faller de fem dagene her innunder de femten dagene med praksis, og det var vel ganske stor enighet om at vi skjønte ikke helt hvordan det kunne kobles opp mot skolepraksis, da. Fordi du får jo ikke, altså det vi gjør er jo å få mye teori om analysemetoder, og så sitter vi selv og gjør det samme. Så jeg fikk jo på en måte kanskje ikke noe innblikk i, eller lite innblikk i skoledelen av det, og heller mer innblikk i koder og kategorier og sånne ting.

Her ser vi hvordan «koder og kategorier» blir ansett som noe annet enn noe en typisk forbinder med praksis. Dette kan tyde på at studentenes oppfatning av praksis er direkte knyttet til det å være på en skole og snakke om undervisning uten å systematisk kategorisere det som skjer eller ta utgangpunkt i ulike forskningsspørsmål for å vite mer om for eksempel elevdeltagelse, elevenes oppfatninger av undervisningen eller lærerens refleksjoner. Koding og kategorisering blir sett på som mer relevant for forskning enn for praksis, noe blant andre Håvard setter ord på:

Håvard: Jeg har reflektert litt over at når vi først begynte på lektorprogrammet så handlet det jo om å ta på seg lærerbrillene og se klasserommet fra en annen vinkel enn det vi hadde gjort tidligere. Og det følte jeg at ... analysepraksisuka ga litt hjelp til å finne ut hva forskerbrillene var og hvordan man på en måte skal begynne å forholde seg til klasserommet og praksis som ... litt som forsker da.

Ved å bruke «learning to notice»-rammeverket og legge opp til en systematisk tilnærming til artefaktene fra praksis er det skapt en tydeligere progresjon fra tidligere praksisperioder (med «lærerbriller») til denne praksisformen (med «forskerbriller»). Håvard trekker frem at det kan være fint for lærerstudenter å bli minnet på at de også kan bruke utdanningen til «å bli forsker, og ikke bare lærer». Noe han sier mindre om, er overføringsverdien fra de måtene forskere jobber på, til det lærere gjør i klasserommet. Marie kommenterer nettopp dette aspektet rett etter at Håvard har snakket om det å kunne bli forsker - og hun kobler det også til det å være utøvende lærer:

Marie: Jeg synes det er veldig fint at vi får rom til at de her 15 praksisdagene [hvorav fem er analysepraksis], som på en måte kommer litt på rest, også kan brukes til å ikke bare være lærer, men å se lærerrollen fra, som du sier, et forskerperspektiv. Det er jo det man gjør, egentlig. Og jeg mener jo at det er veldig nyttig ute i klasserommet. Jeg kan ikke evaluere min egen praksis med mindre jeg vet hva som funker og ikke funker, og hvordan man vet hva som funker og ikke funker.

Gjennomgående får analysepraksis positiv omtale fra studentene, og flere trekker frem i spørreskjemaet at det har vært både intenst, sosialt og lærerikt. Det er også mange som fremhever at det har vært bra å jobbe i grupper med bestemte fokus over flere dager. Et flertall opplevde også uka som relevant, og selv om den først og fremst nok anses som relevant for masterskriving, klarer studentene i 
intervjuene også å se annen relevans når de blir spurt om det. Studentene i intervju er også gjennomgående positive til nytenkning når det gjelder hva praksis kan være. Marie fremhever at analysepraksis er «en kul praksisvariant» og at det gir mer enn bare tradisjonell observasjonspraksis på en skole:

Marie: Nei, altså, hvis alternativet er observasjon i, på en skole, definitivt så har dette gitt meg mer, ikke bare til masteren, men fordi at ... ja ... selv om jeg ikke skal skrive en kvalitativ master, så er det veldig lurt å vite hvordan skoleforskning funker for at jeg i det hele tatt skal kunne vurdere det og implementere det i praksisen, i min lærepraksis, og, ja, lærerhverdag da. Så sånn sett så har det vært definitivt en fin måte ... Jeg synes det er kjempespennende også å få andre typer praksisperioder.

\section{Analysepraksis fungerer masterforberedende}

Analysepraksisuka er lagt i starten av studentenes 9. semester, rett før de skal i gang med datainnsamling og arbeid med selve masteroppgaven. Denne timingen kan synes viktig for studentene, at uka fremstår som et slags intensivkurs der de får oversikt over og praktisk erfaring med ulike metodiske tilnærminger til data før de selv skal gjøre egne analyser i masteroppgaven. Resultatene fra spørreskjemaet viser at de fleste av studentene i stor grad opplever analysepraksis som masterforberedende (se tabell 3).

Tabell 3. Fordeling av svar på spørsmålet: I hvilken grad opplever du at analysepraksis gjør deg bedre forberedt til arbeidet med din masteroppgave?

\begin{tabular}{|l|c|}
\hline \multicolumn{1}{|c|}{ Svar } & Antall \\
\hline I svært stor grad & 7 \\
\hline I stor grad & 15 \\
\hline Middels & 13 \\
\hline I mindre grad & 0 \\
\hline I liten grad & 4 \\
\hline
\end{tabular}

22 studenter svarer at analysepraksis i svært stor eller stor grad er masterforberedende, mens 13 studenter svarer middels på dette spørsmålet. 27 av studentene utdyper dette i de åpne spørsmålene i spørreskjemaet, og mange nevner eksplisitt at de hadde stort utbytte av å lære om transkribering og koding, og at dette var noe de hadde lite erfaring med fra før. Et svar som illustrerer dette er følgende:

Jeg lærte mye om koding og perspektiver knyttet til metode som blir til stor hjelp under masterskriving. Samlet sett så var det mye verdifull kunnskap fordi vi kunne ta det med oss såpass nærme masterforberedelsene.

De aller fleste studentene nevnte i fritekstsvar og i intervjuene «koding», «kategorier» eller «analyse» når de ble spurt om det viktigste de hadde lært. Dette kan tolkes som at de har fått et innblikk i hvordan det å sette merkelapper på praksis hjelper dem til å legge merke til enkelte ting, og ikke andre, i tråd med tankegangen $i$ et «learning to notice»-rammeverk. Flere studenter omtaler også 
analysepraksisuka som motiverende for prosessen med eget masterarbeid, slik dette svaret illustrerer:

Praksisen var veldig nyttig og spesifikk med tanke på masterskriving, og jeg sitter igjen med et stort utbytte og iver etter å komme i gang med å analysere mitt eget datamateriale!

Det er likevel fire studenter som i spørreundersøkelsen svarer at analysepraksis i liten grad forberedte dem til arbeidet med masteroppgaven. Det kan synes som at dette er studenter som skal bruke kvantitative metoder i sin master, og som mener at de i liten grad fikk mulighet til å prøve ut metoder spesifikt relatert til sin master. For eksempel utdypet en av disse studentene det slik i det åpne svarfeltet:

Liker det at praksisformen ikke nødvendigvis sender deg ut i skolen, at man kan arbeide rettet mot masteroppgaven og lette litt på trykket der. Tror flere opplevde at uka var nyttig for masteroppgaven, men jeg sitter ikke med samme opplevelse, mest fordi jeg skal skrive kvantitativt.

Her ser vi at studenten mener at masterrelevans har å gjøre med hvorvidt metodene i analysepraksis er de samme som de du selv skal bruke i masteroppgaven, noe flere studenter uttrykte - ikke minst alle de som mener uka hadde høy relevans fordi de fikk bruke metoder de selv skal anvende i masteroppgaven.

I intervjuene ble det også diskutert i hvilken grad analysepraksis var masterforberedende - fordi studentene selv trakk frem dette som et vesentlig aspekt ved hele uka. Også her ble det tydelig at studenter som selv skulle bruke kvalitative metoder og ta i bruk ulike former for koding og transkripsjon, opplevde mer relevans for egen master enn de som skulle skrive en mer kvantitativ master på et større forskningsprosjekt. For eksempel sier Marie, som skal skrive en master med kvantitative analyser, at hun likte analysepraksis og syntes det var «spennende å gjøre de tingene» og lærte noe av det, men også:

Marie: Selvfølgelig satt jeg inne og håpet at vi kunne jobbet med ting som var litt nærmere min ... mine interesser og min master da. Jeg forstår jo likevel at dette var veldig nyttig for majoriteten av oss, fordi vi er bare noen få som skriver kvantitativt tror jeg.

Studenten Nina, som selv skulle skrive kvantitativt i egen master, gir uttrykk for at også de som skulle gjennomføre primært kvantitative analyser, vil kunne ha utbytte av analysepraksis:

Nina: De aller fleste skal jo ha en kvalitativ undersøkelse i sin master, så det, det treffer veldig mange. Og dette med koding kan jo fint treffe, selv om du ikke har en kvalitativ master. Så det er på en måte ... det gir veldig gode erfaringer, tror jeg. Sånn at du plutselig ikke, når du skal begynne etter jul og se «hva er det jeg har av data?», at du får litt sånn sjokk, men at du på en måte har fått en smakebit på det. Så det er på en måte en del av forberedelse, føler jeg, mot master. Også gir det jo veldig innsikt da, når du senere sitter og leser forskjellige mastere eller forskjellige forskningsrapporter, at du på en måte vet litt av det som ligger bak, tenker jeg. At det på en måte gir deg forståelse for, for både validitet og reliabilitet og sånne ting når du faktisk sitter og leser. Og sånn 
«hva jeg savner her at de hadde snakket noe mer om koding!», fordi at jeg vet selv alt som kan på en måte være innad i det da. Ja.

Det er ingen tvil om at analysepraksisuka har prioritert kvalitative datakilder og metoder. Dette bygger delvis på at de kvalitative datakildene oppleves som «nærmere praksis» ved at de gir mer direkte og detaljert innsyn i klasseromspraksis gjennom video av undervisning og samtaler med lærer og elever, og analysepraksisuka er en praksisuke. Valget av kvalitative data begrunnes også med at disse dataene er spesielt godt egnet til jobbe systematisk med en «learning to notice»-tankegang, jamfør litteraturgjennomgangen. Vi ser samtidig at spørreundersøkelsen til klassen og de kvantitative metodene med fordel kunne vært løftet frem i større grad, og at vi også kunne anvendt disse artefaktene i større grad for å hjelpe studentene å legge merke til lærerens faktiske undervisningspraksis og hvordan elevene selv vurderte lærerens undervisning. Spørsmålet er likevel om det ville vært tilstrekkelig til å tilfredsstille de studentene som har spesialisert seg på kvantitative metoder og som gjerne skriver masteren sin på større datasett innhentet via store pågående forskningsprosjekter som PISA-undersøkelsen eller de nasjonale prøvene. Utgangspunktet for analysepraksisuka er at lærerstudentene, som lærere og som forskere, trenger oversikt over ulike måter å tilnærme seg praksisartefakter på for å få innsikt i undervisning og læring, og at det ikke er en ulempe å få god kjennskap til de kvalitative metodene selv om dette ikke er utgangspunkt for egen master. Vi kan legge til at det har vært et gjennomgående tema i evalueringene i metodeemnene på master at studentene gjerne ser mest relevans i undervisningen om metoder de selv skal bruke, og mindre i alle andre metoder - selv om metodeemnet har som uttalt ambisjon å forberede dem på spennet av metoder alle som forholder seg til utdanningsforskning bør ha grunnleggende kjennskap til. Spørsmålet om opplevd relevans handler også om forventninger, og om hvorvidt studentene forventer at analysepraksis først og fremst skal gi dem direkte erfaring med de konkrete analysene de selv skal gjøre. Som studenten Håvard påpekte da Marie sa hun satt og håpet på flere oppgaver som var nærmere hennes interesser og hennes master:

Håvard: Jeg tror man får et veldig annet inntrykk hvis man ikke sitter og venter på det kvantitative, på en måte. Hvis man ikke tenker på dét.

En tydelig implikasjon fra både spørreskjemaene og intervjuene, er at formålet med analysepraksis godt kan bli enda tydeligere. Sammenhengen mellom master og analysepraksis virker tydelig, spesielt for de som gjør kvalitative analyser i egen master, men hva analysepraksis gir av innsikt om forskning generelt (uavhengig av metode) - som et utgangspunkt for å legge merke til og reflektere rundt praksis - kan nok bli tydeligere. Som vi skal se i det følgende, henger dette spørsmålet om relevans nært sammen med hvorvidt studentene mener det de gjør i analysepraksis egentlig er en praksisform - og hva slags innsikt den kan gi sammenlignet med mer tradisjonell praksis. 


\section{Oppsummerende betraktninger og implikasjoner for lærerutdanningen}

I denne artikkelen har vi undersøkt i hvilken grad og hvordan lektorstudentene oppfatter at analysepraksis har bidratt til deres forsknings- og profesjonsforberedelser. Studien viser at studentene både er åpne for og ser fordeler med en slik alternativ praksisform. De fleste opplevde at det å analysere ulike data fra klasserommet på en så systematisk måte har bidratt i forberedelsene til eget masterarbeid. Aller mest relevans ble rapportert fra studenter som skulle skrive kvalitative masteroppgaver, men også studenter med kvantitative datasett i masteren evnet å se relevans til egen forskning. Funnene viser dessuten at analysepraksis ble sett på som en progresjon fra ordinær skolepraksis, men at studentene nok likevel opplevde uka som mer knyttet til innsikt i forskning enn innsikt i lærerprofesjonen. Et tydelig forbedringspotensial vi vil diskutere, er derfor hva som kan gjøres for at denne type praksis ikke bare oppleves som relevant innsyn i forskning, men som også gir forståelse for hvor viktig et slikt innblikk i forskning er for alle profesjonelle lærere og utviklingen av deres (undervisnings)praksis. Lærere forventes å forholde seg aktivt til andres forskning gjennom hele yrkesløpet, og å tilnærme seg egen undervisning på en systematisk og analytisk måte.

En kan derfor tenke seg at en tydeligere innramming i et rammeverk som «learning to notice» med fordel kunne vært anvendt gjennom hele studieløpet, og flere studenter sier også at de har savnet å jobbe så systematisk med observasjon og andre metoder som det de fikk under analysepraksis. Det er også mulig at studentenes opplevelse av at de ikke tidligere har hatt det analytiske blikket på praksis, kan skyldes måten observasjon som fenomen ofte rammes inn på når studentene kommer ut i skolene i praksis. Greier de da å koble den kompetansen de har fått på observasjon fra campus til den aktiviteten det er å observere undervisning i praksis? Eller blir det mer til at de «ser på» undervisningen fra bakerst i klasserommet? Her vil vi fremheve at video ofte trekkes frem som revolusjonerende når det gjelder muligheten til å fange opp mye av klasserommets kompleksitet for å undersøke konkrete situasjoner eller trekk ved undervisningen systematisk, spesielt dersom det er enighet om hva som skal observeres på forhånd. Det at mange studenter i fellesskap kan diskutere artefakter fra klasserommet med støtte fra erfarne lærerutdannere, mener vi også kan ha vært med på å øke det opplevde læringsutbyttet for studenter som mener dette var en mer fokusert måte å se undervisning på. Dette er i samsvar med forskning som fremhever at studenter trenger gode støttestrukturer for å få utbytte av praksisopplæringen (se for eksempel Darling-Hammond et al., 2005).

En annen utfordring vår studie viser, som har god gjenklang i den internasjonale forskningen, er den noe snevre forståelsen av «teori» og "praksis» mange ofte uttrykker (Grosssmann, Hammerness et al., 2009). Dersom studentene ser på praksis utelukkende som noe som utspiller seg der og da i et klasserom, og ikke noe som for eksempel kan fanges på film eller gjenspeiles i elevintervjuer, er det lite trolig at de vil kunne se hvordan erfaringer fra analysepraksis vil kunne 
gjøre deg til en bedre lærer. Vi tror derfor det er helt avgjørende at lærerutdanninger som ønsker å utvikle nye former for praksis, gjerne på campus eller i mer systematiske vekslinger mellom praksisskoler og campus, anerkjenner at dette også fordrer en betydelig utvidelse i hva lærerutdannerne og studentene legger i begrepet praksis. Her er det også grunn til å adressere myten om at en blir bedre til å gjennomføre undervisning først og frem av å gjennomføre undervisning selv. En rekke studier viser at det å systematisk analysere egen og andres undervisning etter at denne er gjennomført, og gjerne i sammenheng med fremtidig planlegging av undervisning, kan ha positiv effekt på både lærerstudenter og læreres undervisning (se f.eks. Sun \& van Es, 2015; Metcalf et al., 1996).

Vi tror også at det er behov for å ta inn over seg i enda større grad at studentene trenger støtte til å se overføringsverdiene mellom det å kunne noe om forskningsmetoder og det å utvikle egen praksis. Det er ikke vår hensikt å argumentere imot læreres gjennomgående og uformelle egenrefleksjon over det som skjer i klasserommet, men dataene vi har vist i denne artikkelen synliggjør et stort rom for forbedring fra lærerutdanningens side når det kommer til forståelsen av hvordan forskning kan inngå i - og informere - praksis. Dette er et svært viktig poeng, da mye skoleforskning (om ikke all) har til hensikt nettopp å belyse, dokumentere og til dels forbedre praksisfeltet. Da er det avgjørende at studentene får nok rom til å diskutere hvordan ulike metodiske innganger til praksis vil prege de konklusjonene som trekkes og ikke minst overføringsverdien denne forskningen kan ha (eller mangle) til ens egen praksisutøvelse. Dersom en ønsker seg lærende lærere, som hele sitt profesjonelle liv forholder seg til forskning og har såkalt forskningsbasert eller forskningsinformert undervisning, ser vi dette som et avgjørende premiss. 


\section{Om forfatterne}

Inga Staal Jenset er førsteamanuensis i pedagogikk ved Universitetet i Oslo. Hun forsker på lærerutdanning og lærerstudentenes utbytte av ulike typer undervisning. Hun leder Theme 4 i det nordiske senteret for fremragende forskning QUINT (Quality in Nordic Teaching) som utforsker bruk av video i lærerutdanningen.

Institusjonstilknytning: Institutt for lærerutdanning og skoleforskning, Universitetet i Oslo, Postboks 1099 Blindern, 0317 Oslo, Norge.

E-post: i.s.jenset@ils.uio.no

Marte Blikstad-Balas er professor i norskdidaktikk ved Universitetet i Oslo. Hun er nestleder for det nordiske senteret for fremragende forskning QUINT (Quality in Nordic Teaching) og leder etterutdanningsprosjektet VIST (Video to support excellence in teaching) der bruk av autentiske videoer frå klasserommet er utgangspunkt for å forbedre egen praksis.

Institusjonstilknytning: Institutt for lærerutdanning og skoleforskning, Universitetet i Oslo, Postboks 1099 Blindern, 0317 Oslo, Norge.

E-post: marte.blikstad-balas@ils.uio.no

\section{Referanser}

Aranda, G., Hobbs, L. \& Clark, J. C. (2019). Video as a tool for reflection on practice in teaching and learning. I L. Xu, G. Aranda, W. Widjaja \& D. Clarke (red), Video-based Research in Education: Cross-disciplinary Perspectives (s. 209-214). London: Routledge.

Ball, D. L. \& Cohen, D. K. (1999). Developing practice, developing practitioners: Toward a practice-based theory of professional education. I G. Sykes \& L. Darling-Hammond (red.), Teaching as the learning profession: Handbook of policy and practice (s. 3-32). San Francisco, CA: Jossey Bass.

Ball, D. L. \& Forzani, F. M. (2009). The work of teaching and the challenge for teacher education. Journal of Teacher Education, 60(5), 497-511. https://doi.org/10.1177/0022487109348479

Barnhart, T. \& van Es, E. (2015). Studying teacher noticing: Examining the relationship among pre-service science teachers' ability to attend, analyze and respond to student thinking. Teaching and Teacher Education, 45, 83-93. https://doi.org/10.1016/j.tate.2014.09.005

Blömeke, S., Gustafsson, J.-E. \& Shavelson, R. J. (2015). Beyond dichotomies. Competence viewed as a continuum. Zeitschrift für Psychologie, 223(1), 3-13. https://doi.org/10.1027/2151-2604/a000194

Brophy, J. (red.) (2004). Using video in teacher education. Boston, MA: Elsevier.

Calderhead, J. (1981). Stimulated recall: A method for research on teaching. British Journal of Educational Psychology, 51(2), 211-217. https://doi.org/10.1111/j.20448279.1981.tb02474.x 
Caspersen, J. \& Raaen, F. D. (2014). Novice teachers and how they cope. Teachers and Teaching, 20(2), 189-211. https://doi.org/10.1080/13540602.2013.848570

Cochran-Smith, M. \& Lytle, S. L. (2009). Inquiry as stance: Practitioner research for the next generation. New York, NY: Teachers College Press.

Conway, P. F. \& Munthe, E. (2015). The practice turn. Research-informed clinical teacher education in two countries. I J.-K. Smedby \& M. Stutphen (red.), From vocational to professional education. Educating for social welfare (s. 146-163). London, England: Routledge.

Darling-Hammond, L., Burns, D., Campbell, C., Goodwin, L., Hammerness, K., Low, E. L., ... Zeichner, K. M. (2017). Empowered Educators: How high performing systems shape teaching quality around the world. San Francisco, CA: Jossey-Bass.

Darling-Hammond, L., Hammerness, K., Grossman, P., Frances, R. \& Shulman, L. (2005). The design of teacher education programs. I L. Darling-Hammond \& J. Bransford (red.), Preparing teachers for a changing world. What teachers should know and be able to do (s. 390-441). San Fransisco: Jossey-Bass.

Fauskanger, J. \&Mosvold, R (2014). Innholdsanalysens muligheter i utdanningsforskning. Norsk pedagogisk tidsskrift, 98(2), 127-139,

Finne, H., Jensberg, H., Aaslid, B. E., Haugsbakken, H., Mathiesen, I. H. \& Mordal, S. (2011). Oppfatninger av studiekvalitet i lcererutdanningen blant studenter, lærerutdannere, øvingslæerere og rektorer. Trondheim: SINTEF Teknologi og samfunn. https://www.regjeringen.no/globalassets/upload/kd/vedlegg/uh/gnist/sintef_studiekvalitet larerutdanningene.pdf

Finne, H., Mordal, S. \& Stene, T. M. (2014). Oppfatninger av studiekvalitet i læererutdanningene 2013. Trondheim: SINTEF Teknologi og samfunn. https://www.sintef.no/globalassets/upload/teknologi_og_samfunn/teknologiledelse/sintef 1127901_oppfatninger-av-studiekvalitet-i-larerutdanningene-2013.pdf/

Finne, H., Mordal, S. \& Ullern, E. F. (2017). Oppfatninger av kvalitet i læererutdanningene 2016. Trondheim: SINTEF Teknologi og samfunn. https://sintef.brage.unit.no/sintefxmlui/bitstream/handle/11250/2569677/sintef_a28066.pdf?sequence=2\&isAllowed=y

Forzani, F. M. (2014). Understanding “core practices” and "practice-based” teacher education: Learning from the past. Journal of Teacher Education, 65(4), 357-368. https://doi.org/10.1177/0022487114533800

Fosse, B. O. (2011). Lererstudenters innramming og forståelse av tilpasset opplcering. En studie av kollektive læringsprosesser i ulike kontekster ved en praktisk-pedagogisk larerutdanning. Doktoravhandling, Det Utdanningsvitenskapelige fakultet, Universitetet i Oslo. https://www.duo.uio.no/bitstream/handle/10852/53231/PhDFosse.pdf?sequence $=1 \&$ isAllowed $=\mathrm{y}$

Gaudin, C. \& Chaliès, S. (2015). Video viewing in teacher education and professional development: A literature review. Educational Research Review, 16, 41-67. https://doi.org/10.1016/j.edurev.2015.06.001

Grossman, P., Compton, C., Igra, D., Ronfeldt, M., Shahan, E. \& Williamson, P. W. (2009). Teaching practice: A cross-professional perspective. Teachers College Record, 111(9), 2055-2100. https://tedd.org/wp-content/uploads/2014/03/Grossman-et-al-TeachingPractice-A-Cross-Professional-Perspective-copy.pdf

Grossman, P., Hammerness, K. \& McDonald, M. (2009). Redefining teaching, re-imagining teacher education. Teachers and Teaching: theory and practice, 15(2), 273-289.

Grossman, P., Hammerness, K. M., McDonald, M. \& Ronfeldt, M. (2008). Constructing coherence: Structural predictors of perceptions of coherence in NYC teacher education programs. Journal of Teacher Education, 59(4), 273-287. https://doi.org/10.1177/0022487108322127 
Hammerness, K., Darling-Hammond, L., Bransford, J., Berliner, D., Cochran-Smith, M., McDonald, M. A. \& Zeichner, K. M. (2005). How teachers learn and develop. I L. Darling-Hammond \& J. Bransford (red.), Preparing teachers for a changing world: What teachers should learn and be able to do (s. 358-389). San Francisco, CA: Jossey-Bass.

Hammerness, K., Klette, K., Jenset, I. S. \& Canrinus, E. T. (2020). Opportunities to study, practice and rehearse teaching in teacher preparation: An international perspective. Teachers College Record, 122(11), 1-46. https://www.tcrecord.org/Content.asp?ContentId=23487

Helgevold, N., Næsheim-Bjørkvik, G. \& Østrem, S. (2015). Key focus areas and use of tools in mentoring conversations during internship in initial teacher education. Teaching and Teacher Education, 49, 128-137. https://doi.org/10.1016/j.tate.2015.03.005

Hiebert, J., Morris, A. K., Berk, D. \& Jansen, A. (2007). Preparing teachers to learn from teaching. Journal of Teacher Education, 58(1), 47-61. https://doi.org/10.1177/0022487106295726

Hsieh, H. F. \& Shannon, S. E. (2005). Three approaches to qualitative content analysis. Qualitative health research, 15(9), 1277-1288.

Ingersoll, R. M. \& Strong, M. (2011). The Impact of Induction and Mentoring Programs for Beginning Teachers: A Critical Review of the Research. Review of Educational Research, 81(2), 201-233. https://doi.org/10.3102/0034654311403323

Jahreie, C. F. (2010). Learning to teach: An activity-theoretical study of student teachers' participation trajectories across boundaries. Doktoravhandling, Det utdanningsvitenskapelige fakultet, Universitetet i Oslo. http://www.uv.uio.no/iped/forskning/aktuelt/aktuellesaker/dokumenter/Learning\%20to\%20teach_Jahreie_PhDThesis.pdf

Jenset, I. S. (2020). The enactment approach to practice-based teacher education coursework: Expanding the geographic scope to Norway and Finland. Scandinavian Journal of Educational Research, 64(1), 98-117. https://doi.org/10.1080/00313831.2018.1502681

Jenset, I. S., Hammerness, K. \& Klette, K. (2019). Talk about field placement within campus coursework: Connecting theory and practice in teacher education. Scandinavian Journal of Educational Research, 63(4), 632-650. https://doi.org/10.1080/00313831.2017.14 $\underline{15968}$

Jenset, I. S., Klette, K. \& Hammerness, K. (2018). Grounding teacher education in practice around the world: An examination of teacher education coursework in teacher education programs in Finland, Norway, and the United States. Journal of Teacher Education, 69(2), 184-197. https://doi.org/10.1177/0022487117728248

Jyrhämä, R., Kynäslahti, H., Krokfors, L., Byman, R., Maaranen, K., Toom, A. \& Kansanen, P. (2008). The appreciation and realisation of research-based teacher education: Finnish students' experiences of teacher education. European Journal of Teacher Education, 31(1), 1-16. https://doi.org/10.1080/02619760701844993

Kennedy, M. (1999). The role of pre-service teacher education. I L. Darling-Hammond \& G. Sykes (red.), Teaching as the learning profession: Handbook of teaching and policy (s. 54-86). San Francisco, CA: Jossey Bass.

Krokfors, L., Kynäslahti, H., Stenberg, K., Toom, A., Maaranen, K., Jyrhämä, R., Byman, R. \& Kansanen, P. (2011). Investigating Finnish teacher educators' views on research-based teacher education. Teaching Education, 22(1), 1-13. https://doi.org/10.1080/10476210.2010.542559

Kunnskapsdepartementet (2009). Læreren: Rollen og utdanningen. St.meld. 11 (2008-2009). https://www.regjeringen.no/no/dokumenter/stmeld-nr-11-2008-2009-/id544920/

Kunnskapsdepartementet (2013). Forskrift om rammeplan for lektorutdanning for trinn 8-13. (FOR-2016-03-15-280). https://lovdata.no/dokument/SF/forskrift/2013-03-18-288 
Kunnskapsdepartementet (2014). Lœrerløftet - på lag for kunnskapsskolen. https://www.regjeringen.no/globalassets/upload/kd/vedlegg/planer/kd_strategiskole_web. pdf

Kunnskapsdepartementet (2017). Lærerutdanning 2025. Nasjonal strategi for kvalitet og samarbeid i lcererutdanningene. https://www.regjeringen.no/contentassets/d0c1da83bce94e2da21d5f631bbae817/kd_nasjo nal-strategi-for-larerutdanningene_nett.pdf

Kunnskapsdepartementet (2018). Veiledning av nyutdannede nytilsatte læerere i barnehage og skole. https://www.regjeringen.no/contentassets/0081e41fad994cfdbb4e0364a2eb8f65/veilednin g-av-nyutdannede-nytilsatte-larere-i-barnehage-og-skole.pdf

Kvale, S. \& Brinkmann, S. (2009). Interviews: learning the craft of qualitative research interviewing. Los Angeles, CA: Sage.

Lampert, M., Franke, M. L., Kazemi, E., Ghousseini, H., Turrou, A. C., Beasley, H., Cunard, A. \& Crowe, K. (2013). Keeping it complex: Using rehearsals to support novice teacher learning of ambitious teaching. Journal of Teacher Education, 64(3), 226-243. https://doi.org/10.1177/0022487112473837

Lejonberg, E. (2018). Lektorstudenter i praksis: mestringsforventninger og vurderinger av veiledning. Uniped, 41(3), 304-318. https://doi.org/10.18261/ISSN.1893-8981-2018-03$\underline{10}$

Lejonberg, E. \& Tiplic, D. (2016). Clear Mentoring: Contributing to Mentees’ Professional Self-confidence and Intention to Stay in their Job. Mentoring \& Tutoring: Partnership in Learning, 24(4), 290-305. https://doi.org/10.1080/13611267.2016.1252110

Lewis, C. \& Tsuchida, I. (1997). Planned educational change in Japan: The case of elementary science instruction. Journal of Education Policy, 12(5), 313-331. https://doi.org/10.1080/0268093970120502

Lid, S. E. (2013). PPUs relevans for undervisning i skolen. En kartlegging av studenters og nyutdannede lereres oppfatninger. NOKUTs utredninger og analyser. https://www.nokut.no/contentassets/9989482e51f1473786a8037c4b71b46d/lid_stein_erik _ppus_relevans_for_undervisning_i_skolen_2013_3.pdf

Lillejord, S. \& Børte, K. (2014). Partnerskap i lærerutdanningen: En forskningskartlegging. Oslo: Kunnskapssenter for utdanning. KSU 3/2014.

https://www.forskningsradet.no/siteassets/publikasjoner/1254004170214.pdf

LoCasale-Crouch, J., Davis, E., Wiens, P. \& Pianta, R. (2012). The Role of the Mentor in Supporting New Teachers: Associations with Self-Efficacy, Reflection, and Quality. Mentoring \& Tutoring: Partnership in Learning, 20(3), 303-323. https://doi.org/10.1080/13611267.2012.701959

Lund, A. \& Eriksen, T. (2016). Teacher education as transformation: Some lessons learned from a center for excellence in education. Acta Didactica Norge, 10(2), 53-72. https://www.journals.uio.no/index.php/adno/article/view/2483/2458

Lyle, J. (2003). Stimulated Recall: A Report on Its Use in Naturalistic Research. British Educational Research Journal, 29(6), 861-878. https://doi.org/10.1080/0141192032000137349

McDonald, M., Kazemi, E. \& Kavanagh, S. S. (2013). Core practices and pedagogies of teacher education: A call for a common language and collective activity. Journal of Teacher Education, 64(5), 378-386. https://doi.org/10.1177/0022487113493807

Meijer, P. C., de Graaf, G. \& Meirink, J. (2011). Key experiences in student teachers' development. Teachers and Teaching, 17(1), 115-129.

https://doi.org/10.1080/13540602.2011.538502 
Metcalf, K. K., Ronen Hammer, M. A. \& Kahlich, P. A. (1996). Alternatives to field-based experiences: The comparative effects of on-campus laboratories. Teaching and Teacher Education, 12(3), 271-283. https://doi.org/10.1016/0742-051X(95)00037-K

Mosvold, R., Fauskanger, J. \& Wæge, K. (2018). Fra undervisningskunnskap i matematikk til kjernepraksiser. Uniped, 41(4), 401-411. https://doi.org/10.18261/issn.1893-8981-201804-03

Munthe, E., Bjuland, R. \& Helgevold, N. (2016). Lesson study in field practice: a time-lagged experiment in initial teacher education in Norway. International Journal for Lesson and Learning Studies, 5(2), 142-154. https://doi.org/10.1108/IJLLS-12-2015-0047

Munthe, E. \& Rogne, M. (2015). Research based teacher education. Teaching and Teacher Education, 46, 17-24. https://doi.org/10.1016/j.tate.2014.10.006

NOKUT (2019). Hva har NOKUT sagt om kvalitet i praksis? En sammenstilling av informasjon fra NOKUTs tilsynsprosesser. Del av prosjektet Operasjon praksis 2018-2020. Nasjonalt organ for kvalitet i utdanningen. https://www.nokut.no/globalassets/nokut/rapporter/ua/2019/lid_stolinski_kvernenes_hvahar-nokut-sagt-om-kvalitet-i-praksis_4-2019.pdf

NOKUT (2006). Evaluering av allmennlcrerutdanningen i Norge 2006. Del 1: Hovedrapport. Nasjonalt organ for kvalitet i utdanningen. https://www.nokut.no/contentassets/40568ec86aab411ba43c5a880ae339b5/alueva_hoved rapport.pdf

OECD (2005). Teachers matter: Attracting, developing and retaining effective teachers. Paris: Organization for Economic Co-operation and Development. http://www.oecd.org/education/school/34990905.pdf

Parks, A. N. (2008). Messy learning: Preservice teachers' lesson-study conversations about mathematics and students. Teaching and Teacher Education, 24(5), 1200-1216. https://doi.org/10.1016/j.tate.2007.04.003

Rambøll (2016). Veiledning av nyutdannede barnehagelærere og læerere: En evaluering av veiledningsordningen og veilederutdanningen. Rapport til Utdanningsdirektoratet. https://www.udir.no/globalassets/filer/tall-og-forskning/rapporter/2016/evaluering-avveiledningsordningen-sluttrapport.pdf

Rambøll (2021). Evaluering av veiledning av nyutdannede nytilsatte lerere. Sluttrapport til Utdanningsdirektoratet.

https://www.udir.no/contentassets/8f74754444124fe5b3e93415b7472180/sluttrapport_ev aluering-av-veiledning-av-nyutdannede-nytilsatte-larere.pdf

Rørnes, K. (2015). Universitetsskoler i lærerutdanningen: Å koble praksis og teori i lærerutdanningen. I U. Rindal, A. Lund \& R. Jakhelln (red.), Veier til fremragende lererutdanning (s. 75-86). Oslo: Universitetsforlaget.

Sauermann, H. \& Roach, M. (2013). Increasing web survey response rates in innovation research: An experimental study of static and dynamic contact design features. Research Policy, 42(1), 273-286. https://doi.org/10.1016/j.respol.2012.05.003

Seidel, T. \& Stürmer, K. (2014). Modeling and Measuring the Structure of Professional Vision in Preservice Teachers. American Educational Research Journal, 51(4), 739-771. https://doi.org/10.3102/0002831214531321

Sherin, M. G., Jacobs, V. R. \& Philipp, R. A. (2010). Mathematics teacher noticing: seeing through teachers' eyes. New York: Routledge.

Smith, K., Ulvik, M. \& Helleve, I. (2013). Førstereisen: Iæerdom hentet fra nye læereres fortellinger. Oslo: Gyldendal akademisk.

Stigler, J. W. \& Hiebert, J. (1999). The teaching gap: Best ideas from the world's teachers for improving education in the classroom. New York: Free Press. 
Sun, J. \& van Es, E. A. (2015). An exploratory study of the influence that analyzing teaching has on preservice teachers' classroom practice. Journal of Teacher Education, 66(3), 201-214. https://doi.org/10.1177/0022487115574103

Ulvik, M. (2014). Student-teachers doing action research in their practicum: Why and how? Educational Action Research, 22(4), 518-533. https://doi.org/10.1080/09650792.2014.918901

Ulvik, M., Helleve, I. \& Smith, K. (2018). What and how student teachers learn during their practicum as a foundation for further professional development. Professional Development in Education, 44(5), 638-649. https://doi.org/10.1080/19415257.2017.1388271

Ulvik, M. \& Riese, H. (2016). Action research in pre-service teacher education - A neverending story promoting professional development. Professional Development in Education, 42(3), 441-457. https://doi.org/10.1080/19415257.2014.1003089

Wæge, K. \& Fauskanger, J. (2020). Teacher time outs in rehearsals: In-service teachers learning ambitious mathematics teaching practices. Journal of Mathematics Teacher Education. https://doi.org/10.1007/s10857-020-09474-0 